\title{
Pesticides in Ground Water - Natrona County, Wyoming, 2001-02
}

In 1991, members of local, State, and Federal governments, as well as industry and interest groups, formed the Ground-water and Pesticide Strategy Committee to prepare the State of Wyoming's generic Management Plan for Pesticides in Ground Water. Part of this management plan is to sample and analyze Wyoming's ground water for pesticides. In 1995, the U.S. Geological Survey, in cooperation with the Ground-water and Pesticide Strategy Committee, began statewide implementation of the sampling component of the State of Wyoming's generic Management Plan for Pesticides in Ground Water. During 2001-02, baseline monitoring was conducted in Natrona County.

\section{PESTICIDES IN GROUND WATER}

Synthetic organic pesticides are used to control weeds, insects, and other organisms in a wide variety of agricultural and nonagricultural settings. The use of pesticides has helped to make the United States the world's largest producer of food (Barbash and Resek, 1996). Pesticide use, however, has also been accompanied by concerns about

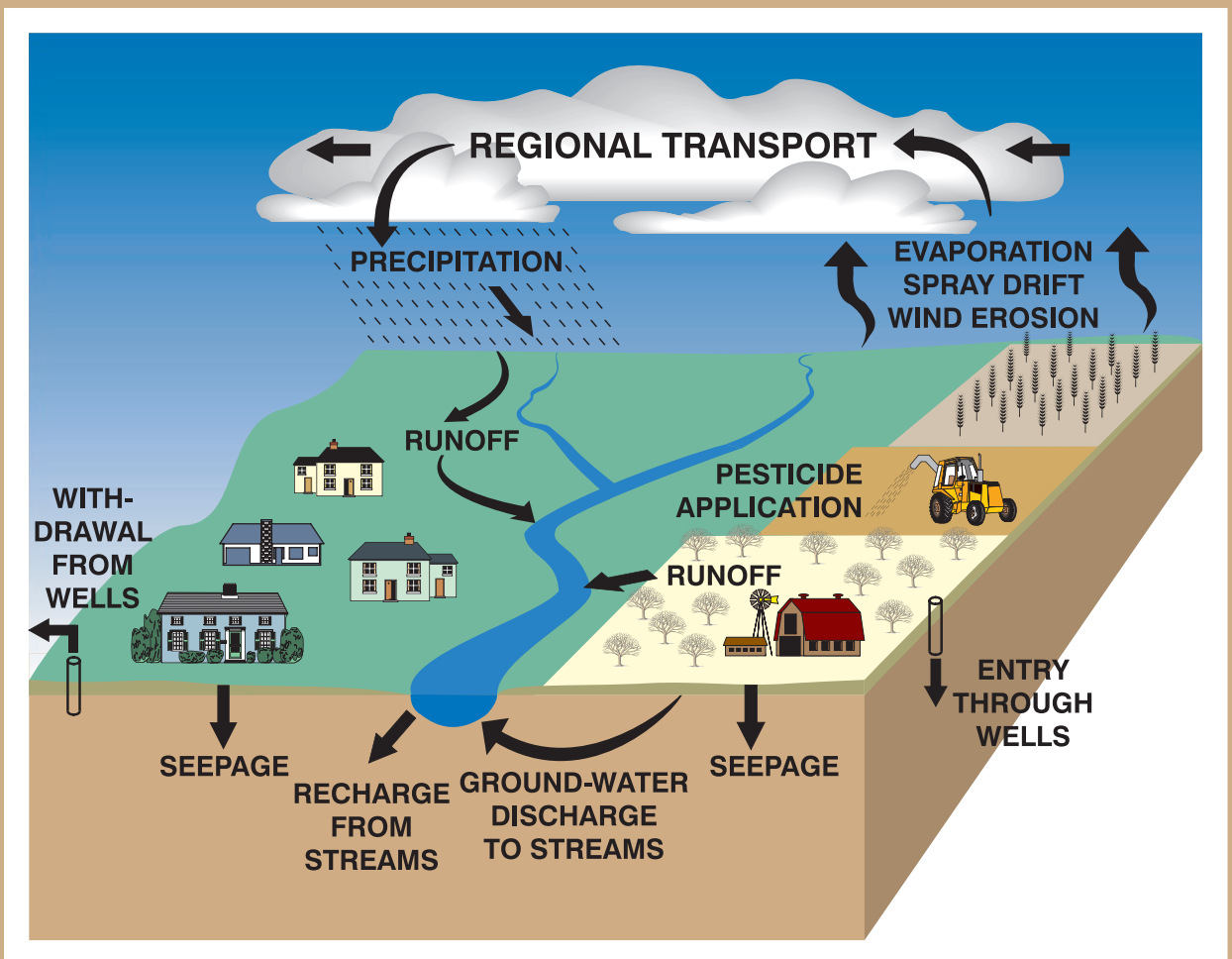

Figure 1. Pathways of pesticide movement in the hydrologic cycle (modified from Barbash and Resek, 1996). potential adverse effects on the environment and human health. A potential pathway for the transport of pesticides is through hydrologic systems, which supply water for both humans and natural ecosystems. Water is one of the primary ways pesticides are transported from an application area to other locations in the environment (fig. 1) (Barbash and Resek, 1996).

Pesticide contamination of ground water is a national issue because of the widespread use of pesticides, the expense and difficulty of remediating ground water, and the fact that ground water is used for drinking water by about 50 percent of the Nation's population. Although application rates and the variety of pesticides used may be greater in urban areas, concern over their presence in ground water is especially acute in rural agricultural areas where more than 95 percent of the population rely upon this resource for drinking water (Solley and others, 1998).

\section{WYOMING'S PESTICIDE MANAGEMENT PLAN}

The Ground-water and Pesticide Strategy Committee (GPSC) has developed the generic State Management Plan for Pesticides in Ground Water for the State of Wyoming (SMP) (Wyoming Ground-water and Pesticides Strategy Committee, 1999). Wyoming was required by the U.S. Environmental Protection Agency to have developed an SMP in order for individuals and organizations to continue using certain pesticides in the state. The SMP includes information relating to individuals and organizations involved with implementation of the SMP, methods of preventing ground-water contamination, ground-water monitoring, and the responses required if pesticides are detected in ground water.

One critical part of the SMP is groundwater monitoring. This ground-water monitoring program has two phases. The first phase, baseline monitoring, is designed

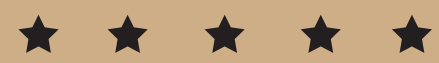

8 Printed on recycled paper

\section{9-2004}


Table 1. Baseline monitoring for pesticides in Natrona County, late summer 2001 and spring 2002.

$[\mu \mathrm{g} / \mathrm{L}$, micrograms per liter; E, trace concentration too small to quantify without estimation; C, estimated value used in calculation]

\begin{tabular}{|c|c|c|c|c|c|c|}
\hline Pesticide & $\begin{array}{c}\text { Pesticide } \\
\text { trade name }\end{array}$ & Pesticide action ${ }^{1}$ & $\begin{array}{c}\text { Number of } \\
\text { detections/ } \\
\text { number of } \\
\text { samples }^{2}\end{array}$ & $\begin{array}{c}\text { Maximum } \\
\text { concentration } \\
(\mu \mathrm{g} / \mathrm{L})\end{array}$ & $\begin{array}{c}\text { Average } \\
\text { concentration } \\
\text { of detections } \\
(\mu \mathrm{g} / \mathrm{L})\end{array}$ & $\begin{array}{c}\text { Safe drinking } \\
\text { water } \\
\text { standard }^{3} \\
(\mu \mathrm{g} / \mathrm{L})\end{array}$ \\
\hline \multicolumn{7}{|c|}{ Focal pesticides detected in Natrona County ground water } \\
\hline Atrazine & Aatrex & Selective herbicide & $7 / 22$ & 0.2 & $0.06 \mathrm{C}$ & 3 \\
\hline Bromacil & Hyvar XL & Herbicide & $3 / 22$ & 8 & 5 & ${ }^{4} 90$ \\
\hline Picloram & Tordon & Systemic herbicide & $3 / 22$ & 0.3 & $0.1 \mathrm{C}$ & ${ }^{4} 500$ \\
\hline Simazine & Princep & Selective herbicide & $2 / 22$ & 0.04 & 0.04 & 4 \\
\hline Tebuthiuron & Spike & Herbicide & $5 / 22$ & $0.6 \mathrm{E}$ & $0.3 \mathrm{C}$ & ${ }^{4} 500$ \\
\hline \multicolumn{7}{|c|}{ Non-focal pesticides detected in Natrona County ground water } \\
\hline Prometon & Pramitol & Non-selective herbicide & $9 / 22$ & 1 & $0.3 \mathrm{C}$ & ${ }^{4} 100$ \\
\hline \multicolumn{7}{|c|}{ Focal pesticides not detected in Natrona County ground water } \\
\hline $2,4-\mathrm{D}$ & Aldicarb & Aldicarb Sulfoxide ${ }^{5}$ & Cyanazine & Dicamba & Metalachlor & \multirow[t]{2}{*}{ Telone } \\
\hline Alachlor & Aldicarb Sulfone ${ }^{5}$ & Clopyralid & DCPA & Hexazinone & Metribuzin & \\
\hline \multicolumn{7}{|c|}{ Focal pesticides not analyzed in Natrona County ground water (no method of analysis available) } \\
\hline \multicolumn{7}{|c|}{ Difenzoquat Metsulfuron } \\
\hline
\end{tabular}

${ }^{1}$ Meister (1996)

${ }^{2}$ Each of the 11 wells was sampled twice.

${ }^{3}$ U.S. Environmental Protection Agency Maximum Contaminant Level unless otherwise noted (U.S. Environmental Protection Agency, 2002).
${ }^{4}$ U.S. Environmental Protection Agency Lifetime Health Advisory Level (U.S. Environmental Protection Agency, 2002).

${ }^{5}$ Degradation product of aldicarb. to determine what pesticides, if any, have leached into the county's ground water. The second phase, problem identification monitoring, is used to gather additional information about the ground water near wells having significant pesticide detections.

Baseline monitoring is prioritized by a county rank and the vulnerability of the county's ground water to pesticides. During the development of the SMP, the GPSC evaluated each county in Wyoming to determine the potential vulnerability of the county's ground water to pesticides. Each county was ranked according to the extent of cropland and urban areas in the county, and the amount of pesticides sold within the county in 1991 (Wyoming Ground-water and Pesticides Strategy Committee, 1999).

A ground-water vulnerability map was prepared for the uppermost or shallowest aquifer (Hammerlink and Arneson, 1998). A Geographic Information System was used to overlay seven layers describing hydrogeology and land use. Ground water is more vulnerable because of either inherent sensitivity of the hydrogeology, or because of the combination of the sensitivity and associated land use. The map was used to assist in the selection of monitoring sites in each county. The monitoring focuses on areas where the ground water is most vulnerable.

The GPSC selected 18 pesticides (focal pesticides) and 2 degradation products to be sampled as part of the SMP (table 1).
The analytical method used to detect the focal pesticides can also detect 66 other pesticides and degradation products. Any additional pesticides detected are listed in table 1 as non-focal pesticides. Ground water from all wells in the baseline monitoring program was analyzed for the pesticides listed in table 1, with the exception of difenzoquat and metsulfuron, for which analytical methods were not available.

The goal of the ground-water sampling part of the SMP is to collect ground-water samples for pesticide analyses in all 23 Wyoming counties. To date, sampling has been completed in Goshen (1995-96), Park (1997), Washakie (1997-98), Fremont (199899), Lincoln (1998-99), Laramie (1998-99), Big Horn (1999-2000), Sheridan (19992000), Platte (2000-01), Johnson (200001), Crook (2000-01), Natrona (2001-02), Sweetwater (2001-02), Teton (2001-02), and Unita (2002-03) Counties. Sampling began in 2003 in Albany, Converse, and Hot Springs Counties.

\section{GROUND-WATER MONITORING IN NATRONA COUNTY}

Ground water in Natrona County was ranked twelfth most vulnerable to pesticide contamination in Wyoming (Wyoming Ground-water and Pesticide Strategy Committee, 1999). The vulnerability map created by the Spatial Data and Visualization Center
(Hammerlink and Arneson, 1998) identifies three types of ground-water settings as the most vulnerable to pesticide contamination in the county (shown as red or yellow on fig. 2). Unconsolidated Quaternary deposits, including alluvial and terrace deposits, and sand and loess deposits make up the largest vulnerable area in the county. Ground water found in all rocks and deposits, consisting primarily of Cretaceous Cody Shale and Quaternary alluvial deposits, that underlie Casper were considered highly vulnerable. Also considered vulnerable were the mountainous areas in the northwestern part of the county and due south of Casper. The focus of the sampling was in the Casper area and along the North Platte River (fig. 3). Although the surficial geology makes the ground water susceptible to contamination, the large sand deposits north of Casper (trending eastward from near Waltman) and the mountainous areas were not sampled because land use does not create a large potential for contamination, and because sampling locations were not available in these areas.

Eleven wells were selected in Natrona County (fig. 3) for baseline monitoring. All wells were located in Quaternary deposits or Cody Shale in locations deemed most vulnerable to contamination (shown as red on fig. 2). All wells were sampled in late summer 2001 and spring 2002. 


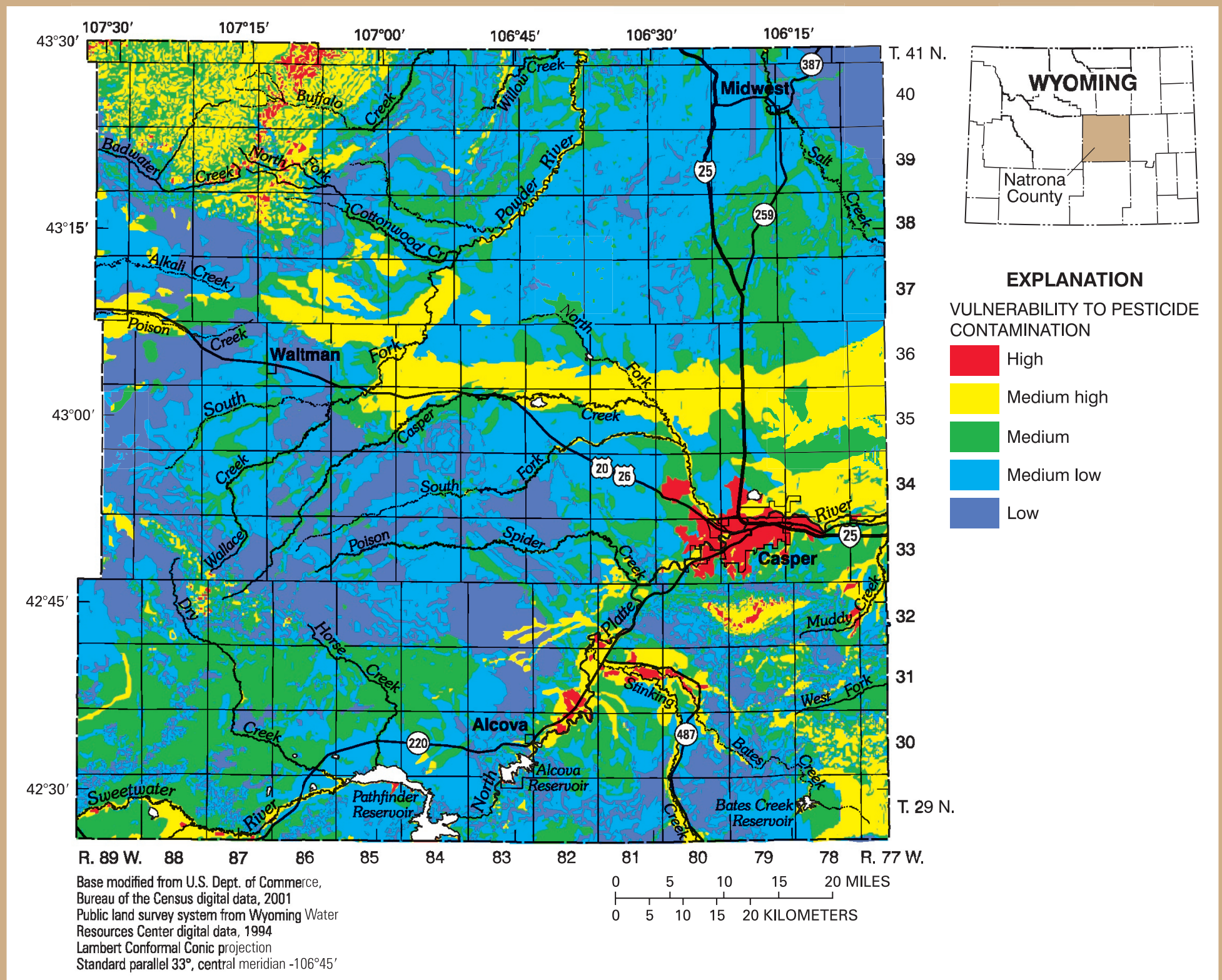

Figure 2. Vulnerability of Natrona County ground water to pesticide contamination (from Hammerlink and Arneson, 1998).

Five of the 18 focal pesticides and 1 nonfocal pesticide were detected in Natrona County (table 1). Pesticides were detected in 6 of 11 wells sampled; however concentrations of each pesticide were less than $1 / 10$ of the applicable drinking-water standard (U.S. Environmental Protection Agency, 2002) (table 1). Many of the detections were at trace concentrations too small to quantify without estimation. Trace concentrations are denoted with an "E" in table 1.

The most commonly detected pesticide in Natrona County was prometon (detected in 9 out of 22 samples). Prometon is the active ingredient in Pramitol, a generaluse pesticide, and its detection is typically associated with urban land use (Barbash and others, 1999). Prometon was also the most commonly detected pesticide in Sheridan, Crook, Johnson, and Teton Counties.

The second most commonly detected pesticide was atrazine. Atrazine is an agri- cultural chemical typically used for weed control in corn and other crops (Meister, 1996).

Bromacil was detected in 3 of 22 samples. A detection of $8 \mu \mathrm{g} / \mathrm{L}$ (parts per billion) of bromacil (drinking-water standard, $90 \mu \mathrm{g} / \mathrm{L}$ ) is the highest level of the pesticide detected in the 14 counties sampled to date as part of this project.

\section{DATA DISTRIBUTION AND AVAILABILITY}

The sampling results have been provided to local groups interested in pesticides in ground water in Natrona County. The information can be used by citizens and local governments to help understand current conditions. Analytical results of the Natrona County sampling can be found in Swanson and others (2002) and Swanson and others (2003), or on the internet at http://waterdata.usgs.gov/wy/nwis/qwdata. Analytical results and fact sheets for all counties sampled to date are available from the U.S. Geological Survey in Cheyenne either by phone, email, or the internet at http://wy.water.usgs.gov/projects/pesticide/.

\section{REFERENCES}

Barbash, J.E., and Resek, E.A., 1996, Pesticides in ground water: Distribution, trends, and governing factors, in Gilliom, R.J., ed., Pesticides in the hydrologic system (v. 2): Lewis Publishing, 590 p.

Barbash, J.E., Thelin, G.P., Kolpin, D.W., and Gilliom, R.J., 1999, Distribution of major herbicides in ground water of the United States: U.S. Geological Survey WaterResources Investigations Report 98-4245, $64 \mathrm{p}$. 


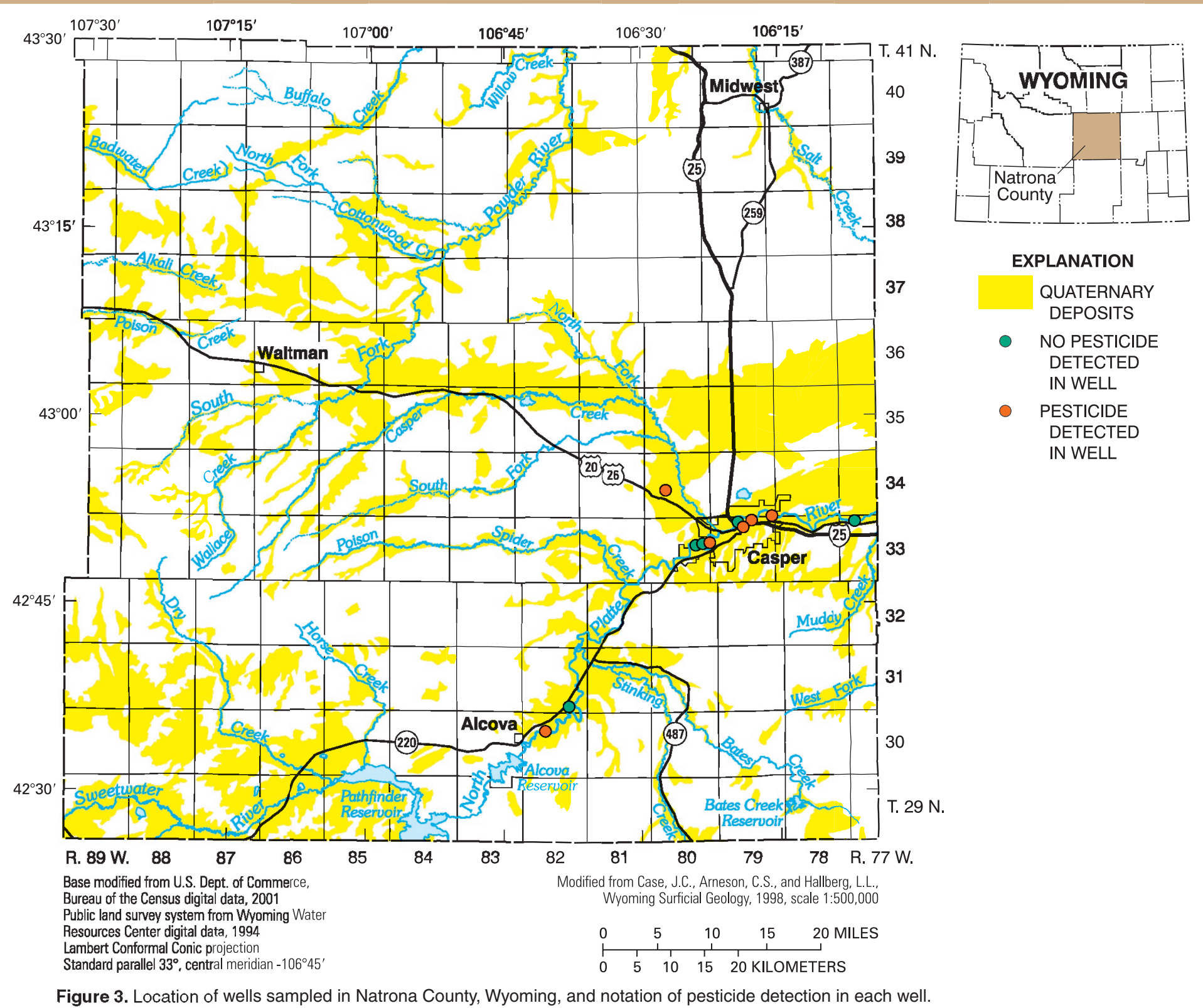

Hammerlink, J.D., and Arneson, C.S., editors, 1998, Wyoming ground water vulnerability assessment handbook: Volume 2. Assessing ground water vulnerability to pesticides: University of Wyoming, Laramie, Spatial Data and Visualization Center Publication SDVC 98-01-2, variable pagination.

Meister, R.T., 1996, Farm Chemicals Handbook: Willoughby, Ohio, Meister Publishing Co., variable pagination.

Solley, W.B., Pierce, R.R., and Perlman, H.A., 1998, Estimated use of water in the United States in 1995: U.S. Geological Survey Circular 1200, $71 \mathrm{p}$.

Swanson, R.B., Blajszczak, E.J., Roberts, S.C., Watson, K.R., and Mason, J.P., 2002, Waterresources data, Wyoming, water year 2001, Volume 2. Ground Water: U.S. Geological Survey Water-Data Report WY-01-2, 127 p.

Swanson, R.B., Blajszczak, E.J., Roberts, S.C., Watson, K.R., and Mason, J.P., 2003, Water- resources data, Wyoming, water year 2002, Volume 2. Ground Water: U.S. Geological Survey Water-Data Report WY-02-2, 140 p.

U.S. Environmental Protection Agency, 2002, Drinking water regulations and health advisories: EPA 822-R-02-038.

Wyoming Ground-water and Pesticides Strategy Committee, 1999, Wyoming generic state management plan for pesticides and ground water: prepared for Wyoming Department of Agriculture, Cheyenne, Wyoming, $103 \mathrm{p}$.

This document was prepared by the U.S. Geological Survey (USGS), the Wyoming Department of Agriculture (WDA), and the Wyoming Department of Environmental Quality, Water Quality Division (WDEQ). All agencies are members of the Ground-water and Pesticide Strategy Committee.

This project has been funded in part with a Section 319 grant from the U.S. Environmental Protection Agency to Wyoming Department of Environmental Quality's Non-Point Source Program.

The use of trade, product, industry, or firm names is for descriptive purposes only and does not imply endorsement by the U.S. Government.

\section{FOR MORE INFORMATION, CONTACT:}

Wyoming Department of Agriculture 2219 Carey Avenue

Cheyenne, Wyoming 82002

(307) 777-7324

\section{Kevin Frederick}

Wyoming Department of Environmental Quality,

Water Quality Division 4th Floor, Herschler Building Cheyenne, Wyoming 82002

(307) 777-7781

\section{Cheryl Eddy Miller}

U.S. Geological Survey, WRD 2617 E. Lincolnway, Suite B Cheyenne, Wyoming 82001 (307) 778-2931

Email: cemiller@usgs.gov

\footnotetext{
- Prepared by Cheryl A. Eddy-Miller and Kendra J. Remley

- Layout prepared by Suzanne C. Roberts
} 